\title{
The oxytocin receptor, luteolysis and the maintenance of pregnancy
}

\author{
D. C. Wathes ${ }^{1}$ and G. E. Lamming ${ }^{2}$ \\ ${ }^{\mathrm{I}}$ Department of Animal Health, Royal Veterinary College, Boltons Park, Hawkshead Road, \\ Potters Bar, Herts, EN6 INB, UK, and '²Department of Physiology and Enoironmental Studies, \\ University of Nottingham, Sulton Bonington, Loughborough, Leics LE12 5RD, UK
}

\begin{abstract}
During luteal regression episodic pulses of oxytocin secretion become coupled to the release of prostaglandin $\mathrm{F}_{2 \alpha}\left(\mathrm{PGF}_{2 u}\right)$ following synthesis of endometrial oxytocin receptors, but in early pregnancy the inhibition of oxytocin receptor formation by the conceptus prevents the development of the pulsatile pattern of $\mathrm{PGF}_{2 \alpha}$ release needed to achieve luteolysis. Oxytocin receptors are present on the luminal epithelium in ovariectomized and anoestrous ewes, in pregnant animals throughout most of gestation (day 21 to term) and in explants of endometrial tissue cultured in vitro. These receptors can be downregulated for a brief period by progesterone (10-12 days in sheep, 12-14 days in cattle). This period of inhibition can be extended by infusion of interferon $\tau$ (IFN- $\tau$ ) (which probably inhibits oxytocin receptor gene transcription) or of oxytocin into the systemic circulation (which may act further downstream, possibly at the level of translation). Oxytocin receptors also develop on the caruncular stroma and deep glands at oestrus, but these need positive upregulation and appear dependent on an oestrogenic environment. Only epithelial receptors are needed to achieve a maximal PGF response to an oxytocin challenge, but the presence of oxytocin receptors does not necessarily confer responsiveness as other factors may influence intracellular coupling mechanisms and precursor availability. The duration of the luteal phase is regulated by the time of the initial post-ovulatory rise in progesterone and the duration of exposure to progesterone. However, the development of oxytocin receptors in the luminal epithelium is not directly preceded by changes in the concentration of either progesterone or its receptor, implying that an intermediary time-dependent mechanism mediates the inhibitory effect of progesterone on oxytocin receptor formation.
\end{abstract}

\section{Hormonal Changes during Luteolysis}

\section{Oxytocin}

Circulating oxytocin concentrations are basal around oestrus, rise from about day 2 of the cycle as luteal oxytocin synthesis becomes established and reach a peak on about day 9 (Wathes and Denning Kendall, 1992). During this period, pulses of oxytocin are superimposed on a continuously increased baseline. In ewes the baseline falls on days 12-1.3 before the onset of luteolysis, although major episodes of secretion continue (reviewed by Flint et al., 1990; Wathes et al., 1993). This pattern of secretion is essentially similar in both pregnant and nonpregnant animals. In pregnant ewes the oxytocin pulses were smaller on days 13-16, although the frequency was unaltered (Hooper et al., 1986). In cows there are no differences in either pulse amplitude or frequency between pregnant and nonpregnant animals on days 14-19 (Parkinson et al., 1992a). 
(a)

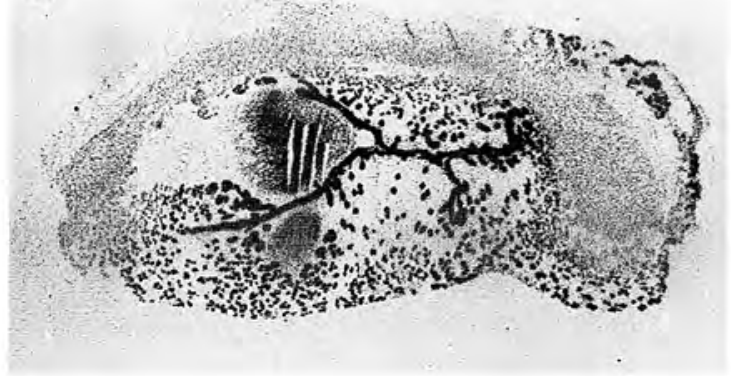

(c)

(e)

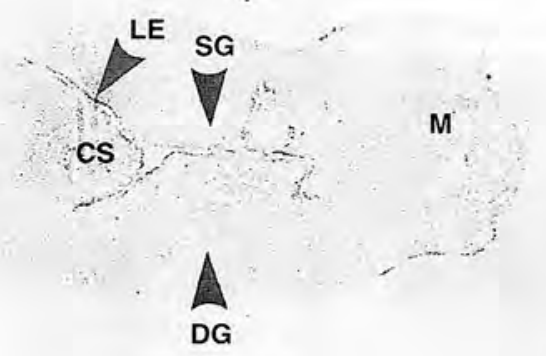

(g)

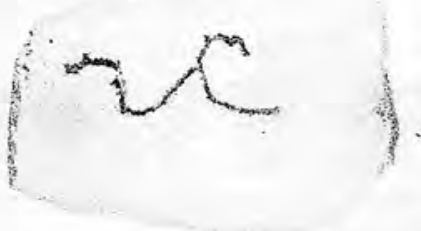

(b)

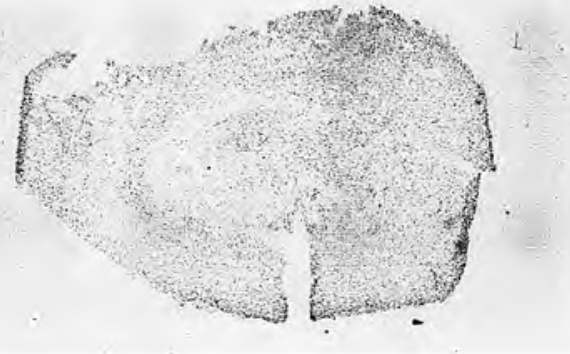

(d)

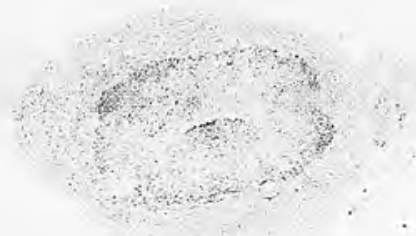

(f)

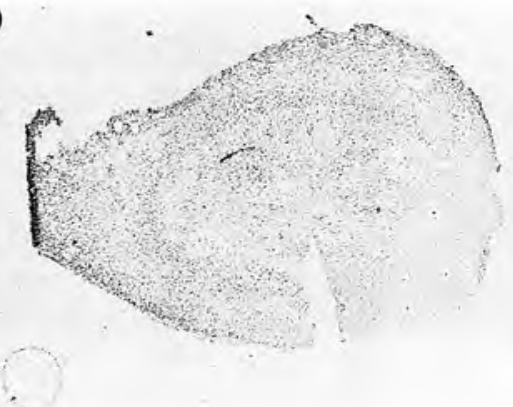

(h)

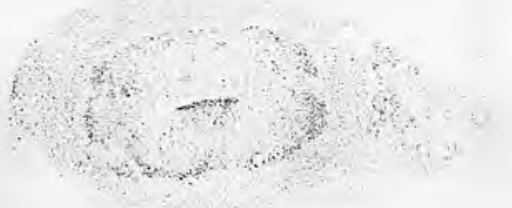

Fig. 2. In situ hybridization showing expression of mRNA encoding the oxytocin receptor in cross-sections of ovine uterus collected at (a,e) oestrus, (b, f) day 12 of the oestrous cycle, (c, g) day 14 of the cycle and (d, h) day 15 of pregnancy. Sections were treated with antisense $(a-d)$ or sense (control) probes (e-h). LE: luminal epithelium; SG: superficial glands; DG: deep glands; CS: caruncular stroma; M: myometrium. The scale bar represents $2 \mathrm{~mm}$. Note the specific hybridization to the luminal epithelium, glands and caruncular stroma at oestrus (a), whereas on day 14 (the time of the onset of luteolysis) receptors are present only on the luminal epithelium (c). The development of these epithelial receptors is blocked in pregnancy (d). 

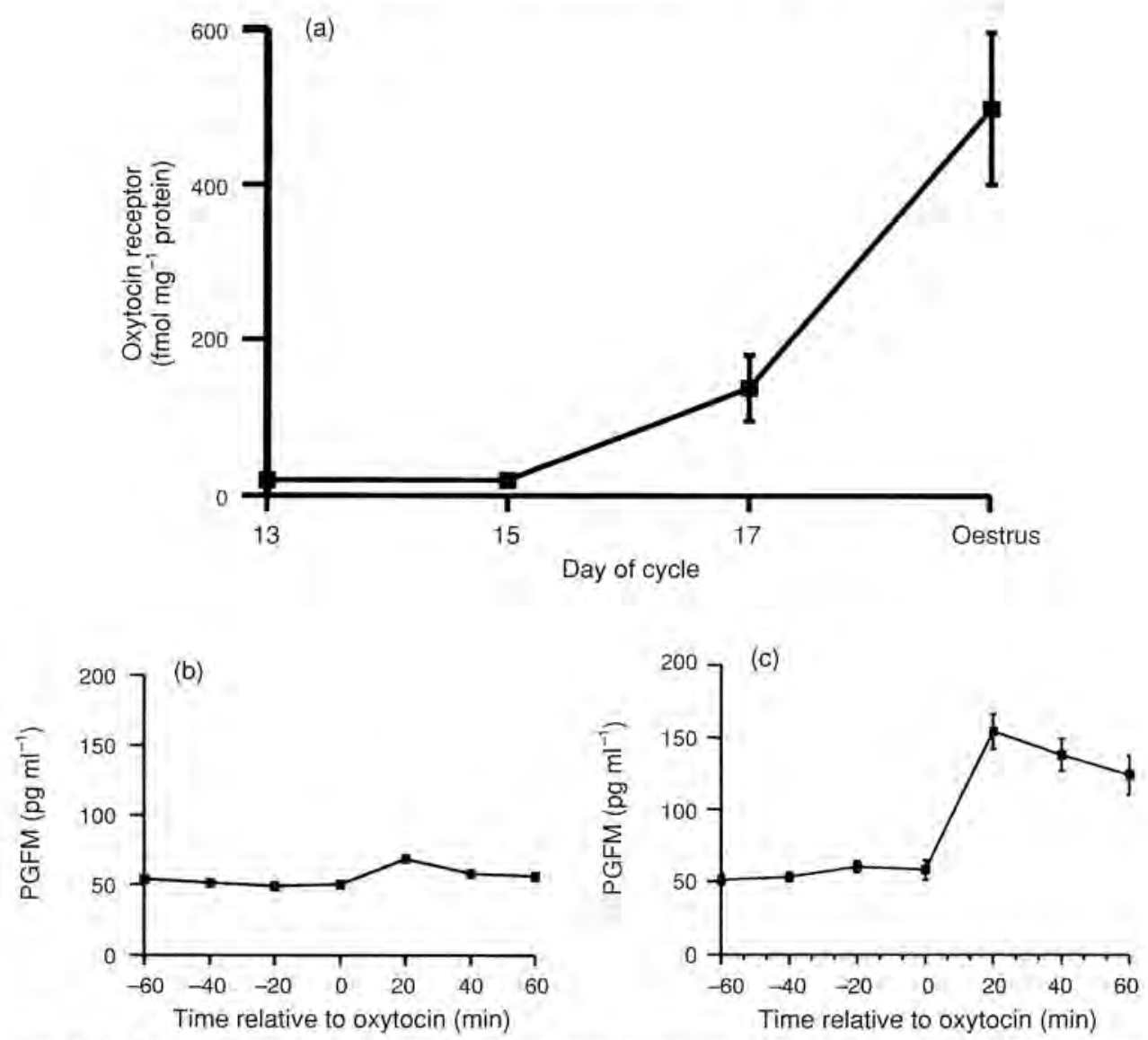

Fig. 3. (a) Oxytocin receptor concentrations in uterine biopsy samples from three cows collected during the late luteal phase. Reproduced with modification from Mann and Lamming (1994) with permission from The Veterinary Record, (b) Response to 50 iu oxytocin on day $15(n=4)$ and (c) response to 50 iu oxytocin on day $17(n=4)$. (Reproduced from Lamming and Mann, 1995a.) The initial receptors that developed by day 17 are capable of generating luteolytic episodes of $\mathrm{PGF}_{2 u}$ release in response to an oxytocin challenge at this time.

pattern of localization seen in these animals resembles that on day 14 of the natural cycle (compare Figs $2 \mathrm{c}$ and $4 \mathrm{~d}$ ).

The role of oestradiol is more contentious, and both stimulatory and inhibitory effects have been reported. Oestradiol treatment alone of ovariectomized ewes decreases the initially high oxytocin receptor concentration to intermediate values (Vallet et al., 1990; Fairclough and Lau, 1992), whereas oestradiol treatment of anoestrous ewes increases the concentration of oxytocin receptors in both the epithelium and stroma (Matthews et al., 1991). The basis for this difference is unclear, as both types of animal start with oxytocin receptors in the luminal epithelium and have low circulating steroid concentrations. If the oestradiol treatment immediately follows progesterone withdrawal in ovariectomized animals (to simulate the normal changes during luteolysis), more oxytocin receptors develop than are stimulated by progesterone treatment alone. Our localization data show that some of these extra receptors form on the deep glands and caruncular stroma in a pattern resembling that occurring at oestrus (Fig. 4b), and they may thus not be of prime importance in mediating a PGF $_{2 \mu}$ response. Experiments on steroid-treated ovariectomized ewes have also shown that the oestrogen:progesterone ratio can alter the pattern of $\mathrm{PGF}_{2 a}$ release in response to an oxytocin challenge at this time (Beard and Lamming, 1994). Increasing the progesterone dose decreased responsiveness, whereas oestradiol had a 


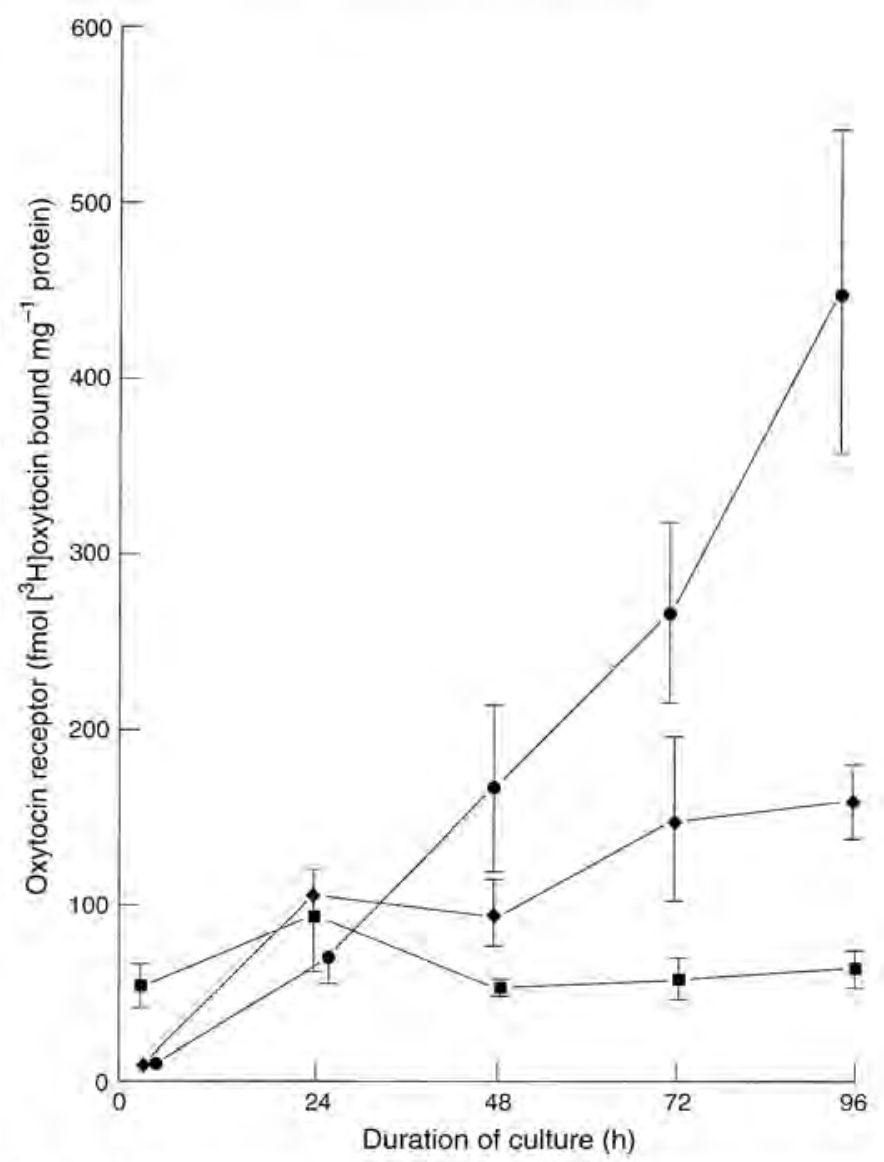

Fig. 5. Concentrations of oxytocin receptor in ovine caruncular endometrium ( ) intercaruncular endometrium $(-)$ and myometrium (E) at time of tissue collection and after $24,48,72$ or $96 \mathrm{~h}$ of culture (mean \pm SEM). Reproduced with permission from Sheldrick et al. (1993).

\section{Regulation by interferon- $\tau$}

The major product of both the ovine and bovine conceptus during the period of preimplantation elongation is a protein belonging to the type I interferon family, now known as IFN- $\tau$. This protein has been the subject of several reviews (Roberts et al, 1992; Stewart et al., 1992) and only those factors relevant to oxytocin receptor regulation will be considered here. IFN- $\tau$ is produced exclusively by trophoblast cells and is first detectable by days 8-10 of pregnancy. Production increases to a peak at days $14-16$ in sheep and days $17-19$ in cattle but then decreases rapidly.

Experiments demonstrating the antiluteolytic properties of IFN- $\tau$ have been performed using either purified conceptus secretory proteins containing IFN- $\tau$ or with recombinant ovine IFN- $\tau$ (roIFN- $\tau$ ). Infusions into the uterus of cyclic ewes on days 12-1.5 extended luteal lifespan and inhibited the pulsatile release of $\mathrm{PGF}_{2 a}$. Systemically administered rbIFN- $\alpha 1$ acted in a similar fashion and was more effective when administration started before day 12 (Parkinson et al., 1992b; Roberts et al., 1992; Mirando et al., 1993a). These treatments prevented the normal development of uterine oxytocin receptors by day 15 in comparison with control (serum-treated) animals. It is uncertain how long such inhibition can be maintained, as insufficient IFN has been available for prolonged treatments. In ovariectomized ewes infusion of IFN- $\tau$ caused effective inhibition only if progesterone treatment was also maintained to day 15 (Ott et al., 1992) and was less successful than in intact animals. If infusion began on day 8 of 
progesterone administration, it caused some reduction in oxytocin receptor concentration by day 13, but was unable to inhibit oxytocin-induced $\mathrm{PGF}_{2 \alpha}$ release (Vallet and Lamming, 1991), suggesting that an additional ovarian factor(s) may be necessary to achieve full inhibition. Recent research has shown that, if the IFN- $\tau$ treatment in the presence of progesterone is coupled with either oxytocin or oestradiol administration, then the oxytocin-IFN- $\tau$ combination is effective in blocking the $\mathrm{PGF}_{2 \alpha}$ response whereas the oestradiol-IFN- $\tau$ combination is not (Payne et al., 1995).

Experiments in ewes with transected uteri have shown that the regulation of oxytocin receptors by IFN- $\tau$ is local rather than systemic. In the unilaterally transected animals the pregnant horn contains a high antiviral activity and a low oxytocin receptor concentration, whereas the nonpregnant hom has low antiviral activity and a high oxytocin receptor concentration (Stewart et al., 1992), with the increases in oxytocin receptors again limited to the luminal epithelium. This demonstrates that the initial development of receptors does not require an altered sex steroid hormone environment.

The inhibitory effect of IFN- $\tau$ is also transient. If endometrial tissue, which is unresponsive to oxytocin challenge in vivo, is removed from day 12,14 or 16 pregnant ewes and treated instead in vitro following removal of the influence of the conceptus, then oxytocin can elicit a PGF $_{2 a}$ response after only $3 \mathrm{~h}$ in culture (Silvia and Raw, 1993). mRNA encoding the oxytocin receptor is not detectable in the endometrium at this stage of pregnancy (Stevenson et al., 1994), so these data imply that gene transcription and translation are activated immediately after removal of IFN- $\tau$ from the endometrial environment. A similar conclusion can be reached from studies in early pregnancy. In ewes mRNA encoding IFN- $\tau$ declines precipitously after day 15 and antiviral activity is low in the uterus by day 21 (Roberts et al., 1992). This coincides with the time of development of luminal epithelial oxytocin receptors as detected by both in silu hybridization and autoradiography (Stevenson et al., 1994). These epithelial receptors remain throughout pregnancy, although their concentration increases further at term (Flick-Smith et al., 1994),

\section{Oxytocin Signalling Pathway}

Many instances have now been recorded in which the concentration of oxytocin receptors measured in endometrial tissue did not correlate well with the amount of $\mathrm{PGF}_{2 a}$ released. In cyclic cattle and sheep the development of endometrial responsiveness to an oxytocin injection coincided with only a minor rise in receptor concentration (Sheldrick and Flint, 1985; Silvia et al., 1991; Mirando et al., 1993b). Similarly, in ovariectomized ewes, the maximum response to oxytocin occurred on day 14 of progesterone treatment, whereas the highest oxytocin receptor concentration was not reached until day 16 (Lau et al., 1992). These discrepancies may to a large extent be explained by evidence showing that oxytocin receptors are required only on the luminal epithelium to evoke a full luteolytic response, and that these constitute only a small percentage of the total potential endometrial oxytocin receptor population. However, ovariectomized ewes and cows and anoestrous ewes have a substantial epithelial receptor concentration (Fig, 4a), yet do not respond to an oxytocin challenge by prostaglandin release (Sharma and Fitzpatrick, 1974; Vallet and Lamming, 1991; Lamming and Mann, 1995). It is, therefore, likely that regulation can also be achieved at points on the pathway distal to the initial coupling of oxytocin to its receptor.

This pathway was studied by Flint et al. (1986), who concluded that stimulation of endometrial prostaglandin synthesis by oxytocin was mediated by an increase in phospholipase C (PLC) which catalysed hydrolysis of phosphoinositides to diacylglycerol and inositol phosphates, with subsequent release of arachidonic acid from diacylglycerol. Arachidonic acid can also be released from phospholipids by increased phospholipase $A_{2}\left(P_{2} A_{2}\right)$ activity. This enzyme is calcium dependent and can be activated by an increase in intracellular $\mathrm{Ca}^{2+}$. This can also be stimulated by phosphoinositide hydrolysis, but it is possible to activate $\mathrm{PLA}_{2}$ as a direct result of $\mathrm{G}$ protein activation, without any accompanying rise in inositol triphosphate, showing that the two pathways can be separated (Fuse and Tai, 1987; Fain et al, 1988).

Several other groups have confirmed the association between oxytocin-stimulated PGF $_{2 \alpha}$ release and an increase in PLC (Mirando et al, 1993b; Silvia and Raw, 1993; Wallace et al, 1993). However, 
quantification of these responses has again shown discrepancies, as it is possible to achieve considerable $\mathrm{PGF}_{2 u}$ release with little increase in PLC, for example using ovine endometrial tissue obtained during early pregnancy (Silvia and Raw, 1993). A further detailed investigation into the relationship between $\mathrm{PLC}$ and $\mathrm{PGF}_{2 \alpha}$ failed to resolve this difference. The time course and specificity of response to various oxytocin agonists and antagonists was consistent with an involvement of PLC, but the treatment of endometrial explants with U-73122, a PLC inhibitor, blocked the ability of oxytocin to stimulate the release of $\mathrm{PGF}_{2 a}$ but did not influence stimulation of PLC activity (Silvia et al., 1994). The same group has also investigated the possible involvement of the PLA pathway (Lee and Silvia, 1994). Treatment of endometrial explants with aristolochic acid, which inhibits PLA $_{2}$ activity, blocked the ability of oxytocin to stimulate $\mathrm{PGF}_{2 \alpha}$ release but did not affect tissue responsiveness to exogenous arachidonic acid, the stimulatory effect of which is exerted distal to PLA. There is therefore good evidence that both PLC and PLA $A_{2}$ can be involved. Experiments to date have involved tissue explants or homogenates, so it remains to be determined whether both pathways are present in all cell types or are perhaps confined to different populations of endometrial cells.

The result of oxytocin binding is activation of the enzymes that mobilize release of arachidonic acid from its storage pool. Regulation of the response is possible at two other points on the pathway. availability of arachidonic acid reserves and of the enzyme prostaglandin endoperoxide $\mathrm{H}$ synthase (PGS) which converts arachidonic acid to $\mathrm{PGF}_{2 \alpha}$. Arachidonic acid is released from phospholipid or triglyceride stores. There is an accumulation of lipid droplets in uterine epithelial cells during both the bovine and ovine oestrous cycles which is stimulated by progesterone treatment (reviewed in Silvia et al., 1991). Progesterone treatment of ovariectomized cattle increases the amount of $\mathrm{PGF}_{2 \alpha}$ which the endometrium can produce in response to an oxytocin challenge (Lamming and Mann, 1995b). Progesterone thus appears to have a dual role-both activation of oxytocin receptors and a time-dependent suppression of oxytocin receptor concentration. Additional evidence for the activational role comes from experiments in prepubertal ewe lambs which have an unresponsive oxytocin receptor population in their uteri; these can also become functional following progesterone treatment (G. E. Lamming and M. Batten, unpublished).

The endometrial concentration of PGS also changes during the oestrous cycle, with an overall increase in activity detectable by days 12-13 in ewes (Huslig et al, 1979; Silvia and Raw, 1993), at least 2 days before the increase in responsiveness to oxytocin. In the early part of the cycle the enzyme is localized principally to the stromal cells, whereas between days 10 and 14 it increases in the epithelial cells of the lumen and superficial glands. This pattern did not differ between pregnant and nonpregnant ewes (Salamonsen et al., 1992). In ovariectomized or oestrogen-treated ewes, PGS is located principally in stromal cells, whereas treatment with progesterone results in a transfer to the epithelial cells (Salamonsen et al, 1992). These results are consistent with the contention that it is the epithelial cells which are involved in the luteolytic release of $\mathrm{PGF}_{2 w}$ but they do not suggest that PGS availability is the rate-limiting step in the development of responsiveness to oxytocin in cyclic ewes. However, in ovariectomized animals the lack of responsiveness to an oxytocin treatment may be due to the different localization of oxytocin receptor (in the epithelium) and PGS (in the stroma). Another possible regulatory step is that enzyme activity may be inhibited by a fatty acid intracellular inhibitor. This is present in bovine endometrium during the mid-luteal phase, decreases in the late luteal phase between days 14 and 17, but remains high at this stage of pregnancy (Helmer et al., 1989).

\section{Steroid Receptors}

\section{Pattern of production}

Oestradiol receptor concentrations in the endometrium reach peak values at oestrus and the early luteal phase, declining significantly in the mid- to late luteal phases in both sheep and cattle ( Ott $e t$ al, 1993; Wathes and Hamon, 1993). The pattern for progesterone binding is similar, although the peak occurs slightly later, in the early luteal phase. The use of immunocytochemistry has revealed a complex pattern, with localization changing between different ovarian compartments with time (Fig. 6). Oestradiol receptor concentrations in all regions (luminal epithelium, glands and stroma) were maximal 

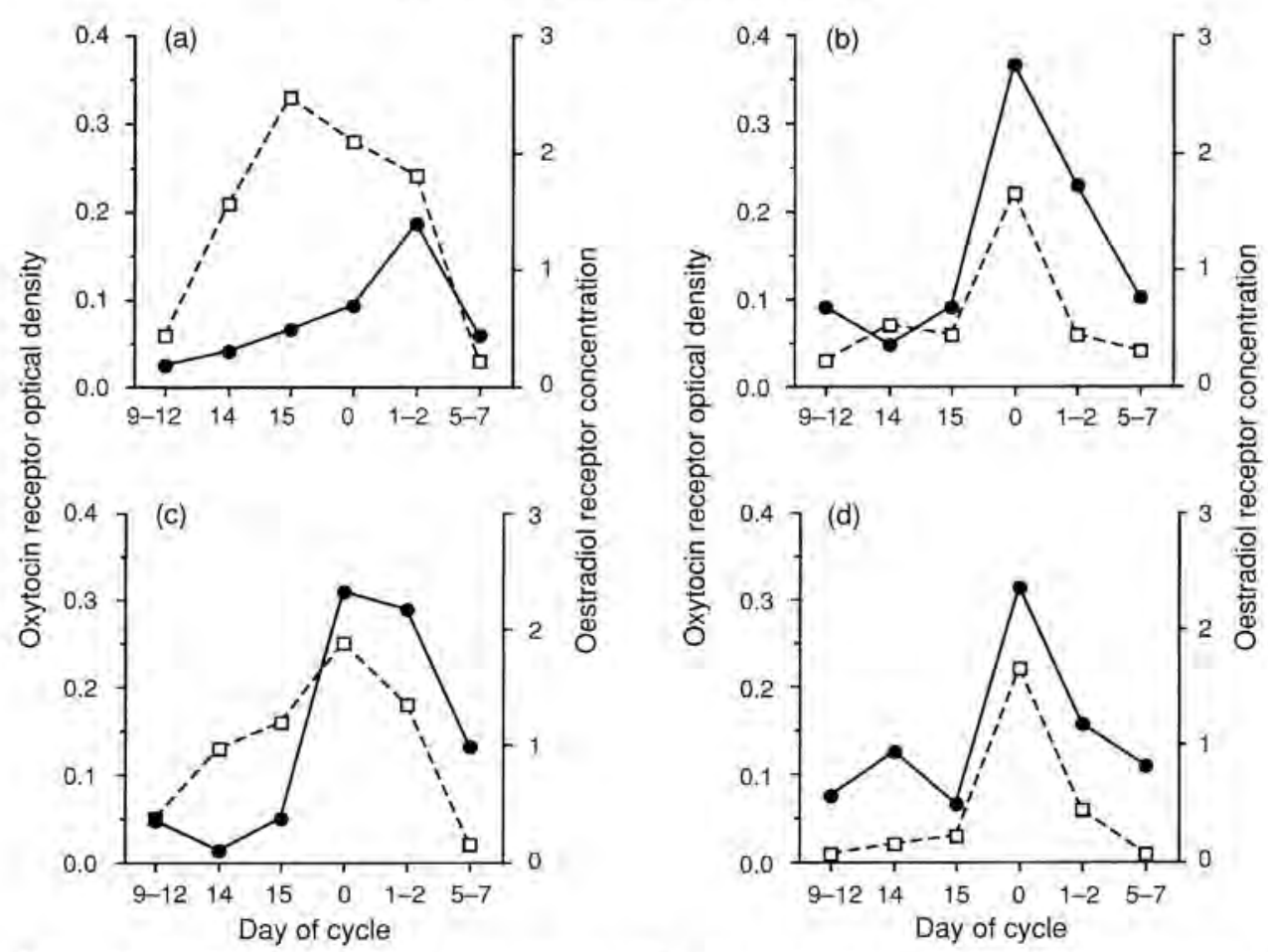

Fig. 6. Comparisons between the mean oxytocin $(\square)$ and oestradiol $(-)$ receptor concentrations in different uterine compartments during the oestrous cycle: (a) luminal epithelium; (b) myometrium; (c) superficial glands; and (d) caruncular stroma. Steroid receptor localization was by immunocytochemistry and was quantified on a scale of 3 (intense), 2 (moderate), 1 (faint) and 0 (absent) nuclear staining. Oxytocin receptor concentration in different regions was assessed by specific binding of $\mathrm{I}^{125}$-labelled oxytocin antagonist (OTA) to uterine sections measured as optical density units (OD) on autoradiographs. Reproduced from Wathes and Hamon (1993) by permission of the Journal of Endocrinology Ltd.

between days $Q$ and 2 of the cycle, declining by day 5 . In most regions concentrations remained low or undetectable in the second half of the luteal phase, with the exception of the deep glands, in which significant immunoreactivity remained throughout the cycle (Cherny et al, 1991; Wathes and Hamon, 1993). There was little change in staining intensity on day 14, although luteolysis was initiated at this time, with the major increase in the luminal epithelium and stroma first occurring on days $15-16$ as animals returned to oestrus. It appeared from the study of Wathes and Hamon (1993) that oxytocin receptor development in the luminal epithelium preceded that of the oestradiol receptors, whereas in the superficial glands and caruncular stroma there was a significant correlation in the timing of the development of oxytocin and oestradiol receptors (Fig. 6). This supports the concept that initial formation of oxytocin receptors in the luminal epithelium is oestrogen independent, but receptors in the rest of the endometrium and myometrium are oestrogen dependent.

Progesterone receptors were present throughout the cycle in stromal and myometrial cells and, although the staining intensity tended to increase on days I-2 and decrease on days 9-14, these changes were not significant because of variations between animals (Wathes and Hamon, 1993). In contrast, the localization to the epithelial cells was highly regulated. Receptors were absent in the luminal epithelium at oestrus, but in both the luminal epithelium and superficial glands they appeared on days $1-2$, rising to a peak on days $5-7$. In the deep glands, both the initial appearance and disappearance were delayed by about 4 days. These data show that the increase in progesterone receptor binding in the early luteal phase is principally associated with formation of additional receptors in the epithelial layers and that this development proceeds in a wave from the lumen towards the myometrium. 
Comparisons between pregnant and nonpregnant animals revealed clear differences in receptor concentrations by days 15-16, as nonpregnant animals showed the increase in oestradiol receptor concentrations associated with the return to oestrus which is blocked in pregnancy. Earlier, small variations were noted for oestradiol receptors (higher in nonpregnant ewes from days 9-15, Findlay et al. 1982) and progesterone receptors (Ott et al., 1993), but other studies failed to detect a difference (Wathes and Hamon, 1993, for both receptors, Ott et al,. 1993, for oestradiol receptors). However, we have recently found a major variation in the intensity of oestradiol receptor staining between the pregnant and nonpregnant horns of ewes with transected uteri in which pregnancy is confined to one horn. Oestradiol receptors were present at concentrations equivalent to those found at oestrus in the nonpregnant horn on day 16, while remaining at low, luteal values in the pregnant horn (G. E. Lamming and D. C. Wathes, unpublished). This finding suggests that, as for oxytocin receptors in the luminal epithelium, the upregulation of oestradiol receptors at oestrus is not initially dependent on a decline in circulating progesterone concentrations, but may occur at this stage unless inhibited by an additional pregnancy-specific factor. This may be an additional function of IFN- $\tau$.

\section{Regulation of steroid receptor concentrations}

There is evidence that oestradiol and progesterone can influence the concentration of their own and each other's receptors (Bergman et al., 1992; Chauchereau et al., 1992). Oestradiol is apparently responsible for stimulating the development of its own receptor in the follicular phase and receptor concentrations decrease in all but the deep glands in the early luteal phase as progesterone concentrations rise; the two events are significantly correlated (Wathes and Hamon, 1993). It is possible that the oestradiol receptors in the deep glands are spared from downregulation by progesterone by the delayed development of progesterone receptors in these cells. Oestradiol receptors in ovariectomized ewes develop following progesterone withdrawal in animals in which the oestradiol concentration is kept constant (Leavitt et al., 1985), again indicating an inhibitory effect of progesterone. Further insights into the regulation of oestradiol receptor concentrations have been obtained by comparing concentrations of processed receptor with those of mRNA. There was a steady increase in endometrial mRNA concentrations between days 10 and 16 in cyclic animals, whereas the receptor concentration rose only on day 16 (Ott et al., 1993). It is possible that in the early luteal phase progesterone inhibits both transcription and translation, but the ability to inhibit transcription is lost first, allowing mRNA to accumulate in the late luteal phase.

McCracken et al. (1981) proposed that the duration of the luteal phase was determined by rising progesterone concentrations in the early luteal phase downregulating its own receptor via a "progesterone block" which lasted about 10 days. Loss of this inhibitory influence was thought to be the initiating factor in luteolysis, as it allowed oxytocin receptor formation to occur. In steroid-treated ovariectomized ewes, progesterone treatment does decrease the progesterone receptor concentration, but several lines of evidence suggest that the relationship is quite complex. The wave of progesterone receptor development moves from the lumen to the deep glands during the early luteal phase as circulating progesterone concentrations rise, and at this stage progesterone is clearly not inhibitory to its own receptor. Likewise, some progesterone receptors remain in the stroma and myometrium throughout the luteal phase, so that the block in this cell type is incomplete. Finally, the appearance of oxytocin receptors in the luminal epithelium between days 14 and 16 in normal cyclic ewes, after 10-12 days of progesterone treatment in ovariectomized ewes and in the nonpregnant horn of animals with a transected uterus, is not preceded by the reappearance of progesterone receptors in the luminal epithelium. In the cyclic animal these do not develop until 1-2 days after oestrus, probably as a result of exposure to high oestradiol concentrations. It is thus hard to link the loss of a negative feedback effect of progesterone on its own receptor directly to the onset of luteolysis.

How then does the timing of the progesterone block operate? One possibility is that progesterone stimulates synthesis of another substance which is inhibitory to oxytocin receptor formation. Synthesis could occur only in the epithelium of the lumen and superficial glands during the time when the presence of progesterone receptors coincides with high circulating progesterone concentrations, that is days $3-7$ of the cycle (Fig. 7). This process could start a clock at a given time in the development of the 
Plasma $P_{4}$

PR on LE

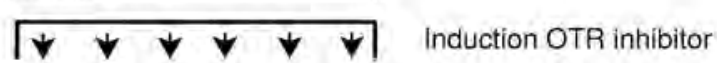

OTR inhibitor

Period of OTR inhibition

OTR on LE

ER on LE
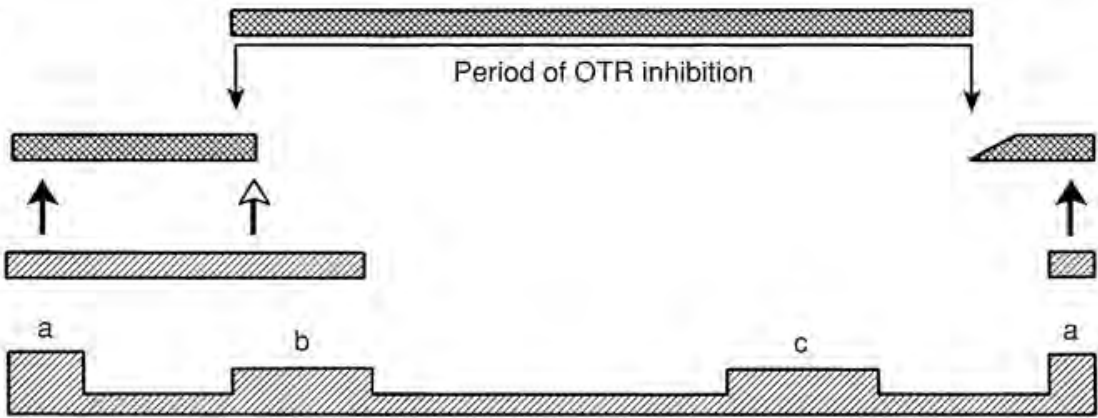

Plasma $E_{2}$

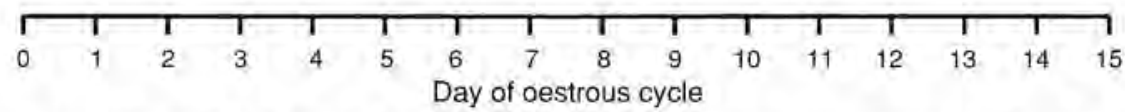

Fig. 7. Diagrammatic scheme for the steroidal regulation of oxytocin receptor development in the luminal epithelium during the ovine oestrous cycle. The induction of an 'oxytocin receptor inhibiting factor' is hypothesized. This is stimulated by progesterone during the time when circulating progesterone concentrations (plasma $\mathrm{P}_{4}$ ) are high and progesterone receptors (PR) are present on the luminal epithelium (LE), i.e. days $3-8$ of the cycle, as shown by the arrowheads. This is able to maintain an inhibitory influence until days 13-14 when oxytocin receptors (OTR) first develop on the luminal epithelium. Low concentrations of circulating oestradiol (plasma $E_{2}$ ) are present throughout the cycle, with additional increases due to (a) ovulatory follicle(s); (b) the first follicular wave and (c) the second follicular wave. Oestradiol is not necessary for oxytocin receptor induction but can cause upregulation when both plasma concentrations are high and oestradiol receptors (ER) are present on the luminal epithelium. This occurs during the follicular phase of the cycle (days 15 and 0 , solid arrows). It could potentially also occur on days $3-4$ (open arrow) if the postovulatory rise in circulating oestradiol precedes the increase in progesterone.

post-ovulatory plasma progesterone rise which could operate in one of two ways. Either the half-life of the putative inhibitor would be such that it would become depleted after about a further 5 days (egg timer effect) or, alternatively, formation of the original inhibitor could initiate a chain of events that would eventually lead to oxytocin receptor formation after a similar period.

\section{Conclusions}

These data indicate that in ruminants the development of oxytocin receptors in the luminal epithelium is the key event that initiates luteolysis. If these form before the luteal oxytocin store is depleted, then a pulsatile release pattern of $\mathrm{PGF}_{2 \alpha}$ will become established in response to episodic secretion of oxytocin from the corpus luteum. The regulation of this oxytocin receptor population is different from that in the rest of the endometrium in that the luminal epithelial receptors are present most of the time. However, they are subjected to a period of negative inhibition by progesterone covering the first 13 days of the ovine luteal phase (about 16 days in cattle). The crucial role of IFN- $\tau$ in maintaining pregnancy is to sustain this inhibition to at least 20 days in sheep (slightly longer in cattle) to allow the loss of luteal oxytocin to occur without provoking a luteolytic response. This action of IFN- $\tau$ is achieved by a local effect on the endometrium.

A large proportion of the endometrial oxytocin receptor population in the deep glands and caruncular stroma does not form until luteolysis is complete and the formation and activity of these 
receptors is probably oestrogen dependent. There is therefore a gradation in control of oxytocin receptor formation from the cells in the luminal epithelium through to the superficial and deep glands. This suggests that, although the epithelial cell layer is continuous, the individual cells within it receive information about their position in the endometrium which has a major impact on the way in which they will regulate their oxytocin receptor population and thus their $\mathrm{PGF}_{2 a}$ response to an oxytocin challenge. The basis for this difference in regulatory mechanisms needs to be established.

\section{References}

Ayad VI, Matthews EL, Wathes DC, Parkinson TJ and Wild ML (1991) Autoradiographic localization of oxytocin receptors in the endometrium during the oestrous cycle of the ewe Jourral of Endocrinology 130 199-206

Ayad VJ, Parkinson TJ, Matthews EL. and Wild ML (1993) Effects of pregnancy and systemic or intrauterine oxytocin infusion on the distribution of endometrial oxytocin receptors in the ewe: an autoradiographic study joumal of Endocrinology $137 \quad 423-431$

Beard AP and Lamming GE (1994) Oestradiol concentration and the development of the uterine oxytocin receptor and oxytocin-induced $\mathrm{PGF}_{2}$ release in ewes Joumal of Reproduction and Fertility $100469-475$

Bergman MD, Schachter BS, Karelus K, Combatsiaris EP, Garcia T and Nelson JF (1992) Up-regulation of the uterine estrogen receptor and its messenger ribonucleic acid during the mouse estrous cycle: the role of estradiol Endocrinology 130 $1923-1930$

Chaucereau A, Savouret JF and Milgrom E (1992) Control of biosynthesis and post-translational modification of the progesterone receptor Biology of Reproduction 46 174-177

Cherny RA, Salamonsen LA and Findlay JK (1991) Immunocytochemical localization of oestrogen receptors in the endometrium of the ewe Reproduction. Ferlility and Development 3 321-331

Fain JN, Wallace MA and Wojcikiewicz RJH (1988) Evidence for involvement of guanine nucleotide-binding regulatory proteins in the activation of phospholipases by hormones FASEB Joumal 2 2569-2574

Fairclough RJ and Lau TM (1992) Hormonal control of concentrations of endometrial oxytocin receptors in the ewe Reproducfion, Ferfility and Development 4 313-320

Fairclough RJ. Moore LG. Peterson AJ and Watkins WB (1984) Effect of oxytocin on plasma concentrations of 13,14dihydro-15-keto prostaglandin $\mathrm{F}$ and the oxytocinassociated neurophysin during the estrous cycle and early pregnancy in the ewe Biology of Reproduction 31 $36-43$

Findlay JK, Clarke IJ, Swaney J, Colvin N and Doughton B (1982) Oestrogen receptors and protein synthesis in caruncular and intercaruncular endometrium of sheep before implantation Joumal of Reproduction and Feritily 64 329-339

Flick-Smith H, Stevenson KR and Wathes DC (1994) Possible role for endometrial oxytocin receptors in ovine parturition Joumal of Endocrinology $\mathbf{1 4 0}$ (Supplement) Abstract P232

Flint APF and Sheldrick EL (1985) Continuous infusion of oxytocin prevents induction of uterine oxytocin receptor and blocks luteal regression in ewes Journal of Reproduction and Fertility 75 623-631

Flint APF, Leat WMF, Sheldrick EL and Stewart HJ (1986) Stimulation of phosphoinositide hydrolysis by oxytocin and the mechanism by which oxytocin controls prostaglandin synthesis in ovine endometrium Biochemical Joumal $237797-805$

Flint APF, Sheldrick EL, McCann TJ and Jones DSC (1990) Luteal oxylocin: characteristics and control of synchronous episodes of oxytocin and $\mathrm{PGF}_{24}$ secretion at luteolysis in ruminants Domestic Animal Endocrinology 7 111-124

Fuse I and Tai H-H (1987) Stimulation of arachidonate release and inositol-1,4,5 triphosphate formation are mediated by distinct G-proteins in human platelets Biochemical and Biophysical Resedrch Communicntions 146 659-665

Gilbert CL, Lamming GE, Parkinson TJ, Flint APF and Wathes DC (1989) Oxytocin infusion from Day Io after oestrus extends the luteal phase in non-pregnant cattle Joumal of Reproduction and Fertility 86 203-210

Helmer SD, Gross TS, Newton GR, Hansen PJ and Thatcher WW (1989) Bovine trophoblast protein-I complex alters endometrial protein and prostaglandin secretion and induces an intracellular inhibitor of prostaglandin synthesis in vifro Journal of Reproduction and Fertility $87421-430$

Hooper SB, Watkins WB and Thorburn GD (1986) Oxytocin, oxytocin-associated neurophysin and prostaglandin $\mathrm{F}_{2 n}$ concentrations in the utero-ovarian vein of pregnant and nompregnant sheep Endocrinology 119 2590-2597

Huslig RL, Fogwell RL and Smith WL (1979) The prostaglandin forming cyclooxygenase of ovine uterus: relationships to luteal function Biology of Reproduction 21 589-600

Kindahl H, Edqvist L-E. Granstrom E and Bane A (1976) The release of prostaglandin $F_{2 \sigma}$ as reflected by 15 -keto-13.14dihydroprostaglandin $\mathrm{F}_{3 n}$ in the peripheral circulation during normal luteolysis in heifers Prosiaglandins 11 871-878

Lamming GE and Mann GE (1995a) Control of endometrial oxytocin receptors and prostaglandin $\mathrm{F}_{2,}$ responses to oxytocin in ovariectomized cows by progesterone and oestradiol Journal of Reproduction and Fertility 103 69-73

Lamming GE and Mann GE (1995b) A dual role for progesterone in the control of cyclicity in ruminants joumal of Reproduction and Fertilify Supplement 49 561-566

Lau TM, Kerton DJ, Gow CB and Fairclough RJ (1992) Increase in concentration of uterine oxytocin receptors and decrease in response to 13,14-dihydro-15-keto prostaglandin $\mathrm{F}_{20}$ in ewes after withdrawal of exogenous progesterone loumal of Reproduction and Ferfility $95 \quad 885-893$

Leavitt WW, Okulicz WC, McCracken JA, Schramm W and Robidoux WE (1985) Rapid recovery of nuclear estrogen receptor and oxytocin receptor in the ovine uterus follow. ing progesterone withdrawal Journal of Steroid Biochemistry 22 687-691

Lee JS and Silvia WJ (1994) Cellular mechanisms mediating the stimulation of ovine endometrial secretion of prostaglandin $\mathrm{F}_{20}$ in response to oxytocins role of phospholipase $A_{2}$ journal of Endocinoloy 141 491-494 
McCracken JA, Schramm W, Barcikowski B and Wilson L. (1981) The identification of prostaglandin $F_{2 \pi}$ as a uterine luteolytic hormone and the hormonal control of its synthesis Acta Velerinaria Scandinavica Supplementum 71 71-88

Mann GE and Lamming GE (1994) Use of repeated biopsies to monitor endometrial oxytocin receptors in cows Veterinary Record 135 403-405

Matthews EL, Ayad VJ and Wathes DC (1991) The elfect of estradiol-17 $\beta$ on oxylocin receptor concentrations in the reproductive tract of the anoestrous ewe Journal of Reproduction and Fertility Abstraci Series 8 81

Mirando MA, Harney JP, Zhou Y, Ogle TF, Ott TL, Moffatt RJ and Bazer FW (1993a) Changes in progesterone and oestrogen receptor mRNA and protein and oxytocin receptors in endometrium of ewes after intrauterine injection of ovine trophoblast interferon Journal of Molecular Endocrinology 10 185-192

Mirando MA, Becker WC and Whiteaker SS (1993b) Relationships among endometrial oxytocin receptors, oxytocinstimulated phosphoinositide hydrolysis and prostaglandin $\mathrm{F}_{24}$ secretion in vitro, and plasma concentrations of ovarian steroids before and during corpus luteum regression in cyclic heifers Biology of Reproduction 48 874-882

Ott TL, Mirando MA, Davis MA and Bazer FW (1992) Effects of ovine conceptus secretory protejns and progesterone on oxytocin-stimulated endometrial production of prostaglandin and tumover of inositol phosphate in ovariectomized ewes Joumal of Reproduction and Ferility 95 19-29

Ott TL, Zhou Y, Mirando MA, Stevens C, Harney JP, Ogle TF and Bazer FW (1993) Changes in progesterone and oestrogen receptor mRNA and protein during maternal recognition of pregnancy and luteolysis in ewes Journal of Molecular Endocrinology 10 171-183

Parkinson TJ, Wathes DC, Jenner LJ and Lamming GE (1992a) Plasma and luteal concentrations of oxytocin in cyclic and early-pregnant cattle loumal of Reproduction and Fertility 94 161-167

Parkinson T], Lamming GE, Flint APF and Jenner LJ (1992b) Administration of recombinant bovine interferon- $\alpha_{1}$ at the time of maternal recogrition of pregnancy inhibits prostaglandin $\mathrm{F}_{20}$ secretion and causes luteal maintenance in cyclic ewes Journal of Reproduction and Fertility $94489-500$

Payne JH and Lamming GE (1994) The direct influence of the embryo on uterine $\mathrm{PGF}_{z i}$ and $\mathrm{PGE}_{2}$ production in sheep Jounul of Reproduction and Fertility 101 737-741

Payne JH, Mann GE and Lamming GE The effects of oxytocin and oestradiol on the actions of conceptus secretory proteins in ovariectomized ewes Joumal of Endocrinology (in press)

Roberts JS and McCracken JA (1976) Does prostaglandin $F_{20}$ released from the uterus by oxytocin mediate the oxytocic action of oxytocin? Biology of Reproduction 15 457-463

Roberts RM, Cross JC and Leaman DW (1992) Interferons as hormones of pregnancy Endocrine Reviezos 13 432-452

Salamonsen LA, Cherny RA and Findlay JK (1992) Studies in vitro of effects of steroid hormones and the blastocyst on endometrial function in the sheep Reproduction, Fertility and Development 4 275-281

Sharma SC and Fitzpatrick RJ (1974) Effect of oestradiol-17 $\beta$ and oxytocin treatment on prostaglandin $\mathrm{F}$ alpha release in the anoestrous ewe Prostaglandins $697-105$

Sheldrick EL and Flick-Smith HC (1993) Effect of ovarian hormones on oxytocin receptor concentrations in explants of uterus from ovariectomized ewes Journal of Reproduction and Fertility $97241-245$
Sheldrick EL and Flint APF (1983) Luteal concentrations of oxytocin decline during early pregnancy in the ewe Journal of Reproduction and Fertility 68 477-480

Sheldrick EL and Flint APF (1985) Endocrine control of uterine oxytocin receptors in the ewe Joumal of Endocrinology 106 249-258

Sheldrick EL, Flick-Smith HC and Dos Santos Cruz GJ (1993) Oxytocin receptor binding activity in cultured ovine endometrium Joumal of Reproduction and Fertility 98 $521-528$

Silvia WI and Raw RE (1993) Activity of phospholipase C and release of prostaglandin $\mathrm{F}_{z_{a}}$ by endometrial tissue from ewes during the oestrous cycle and early pregnancy Journal of Reproduction and Fertility 97 529-537

Silvia WJ, Lewis GS, McCracken JA, Thatcher WW and Wilson L (1991) Hormonal regulation of uterine secretion of prostaglandin $\mathrm{F}_{20}$ Biology of Reproduclion 45 655-063

Silvia WJ, Lee J-S, Trammel DS, Hayes SH, Lowberger LL and Brockman JA (1994) Cellular mechanisms mediating the stimulation of ovine endometrial secretion of prostaglandin $\mathrm{F}_{24}$ in response tó oxytocin: role of phospholipase $\mathrm{C}$ and diacylglycerol Journal of Endocrinology 141 481-490

Stevenson KR, Riley PR, Stewart HJ, Flint APF and Wathes DC (1994) Localization of oxytocin receptor mRNA in the ovine uterus during the oestrous cycle and early pregnancy Journal of Molecular Endocrinology 12 93-105

Stewart HJ, Guesdon FMJ, Payne JH, Charlston B, Vallet JL and Flint APF (1992) Trophoblast interferons in early pregnancy of domestic ruminants Joumal of Reproduction and Fertility Supplement 45 59-68

Vallet $\mathrm{J}$ and Lamming GE (1991) Ovine conceptus secretory proteins and bovine recombinant interferon $\alpha_{1}-1$ decrease endometrial oxytocin receptor concentrations in cyclic and progesterone-treated ovariectomized ewes Joumal of Endocrinology 131 475-482

Vallet JL, Lamming GE and Batten M (1990) Control of endometrial oxylocin receptor and uterine response to oxytocin by progesterone and oestradiol in the ewe Journal of Reproduction and Fertility 90 625-634

Wallace IM Thompson MG, Aitken RP and Cheyne MA (1993) Oxytocin receptor concentrations, inositol phosphate turnover and prostaglandin release by endometrium from ewes induced to ovulate during the early post-partum period Journal of Endocrinology $136 \quad 17-2.5$

Wathes DC and Denning Kendall PA (1992) Control of synthesis and secretion of ovarian oxytocin in ruminants Joumal of Reproduction and Fertility Supplement 45 39-52

Wathes DC and Hamon M (1993) Localization of oéstradiol, progesterone and oxytocin receptors in the uterus during the oestrous cycle and early pregnancy of the ewe Journal of Endocrinology 138 479-491

Wathes DC, Gilbert CL and Ayad VJ (1993) Interactions between oxytocin, the ovaries and the reproductive tract in the regulation of fertility in the ewe. In The Neurohypophysis: A Window on Brain Function, Annals of the New York Academy of Sciences 689 396-410

Zarco L, Stabenfeldt GH, Quirke JF, Kindahl $\mathrm{H}$ and Bradford GE (1988a) Release of prostaglandin $F_{2 u}$ and the timing of events associated with luteolysis in ewes with oestrous cycles of different lengths Joumal of Reproduction and Fertility 83 517-526

Zarco L, Stabenfeldt GH, Basu S, Bradford GE and Kindahl H (1988b) Modification of prostaglandin $\mathrm{F}_{2,1}$ synthesis and release in the ewe during the initial establishment of pregnancy Joumal of Reproduction and Fortility $83517-526$ 